Original Paper

\title{
Produk Inovasi Es Krim Kelor (Moringa oleifera Lam.) sebagai Upaya Pencegahan Stunting Desa Jatisela, Kecamatan Gunung Sari, Lombok Barat
}

\author{
Kurniasih Sukenti ${ }^{*}$, Nining Yuni Rosida ${ }^{2}$, Denda Rosalina ${ }^{3}$ \\ ${ }^{1}$ Fakultas Matematika dan Ilmu Pengetahuan Alam, Universitas Mataram, Mataram, Indonesia \\ ${ }^{2}$ Fakultas Ilmu Sosial dan Politik, Universitas Mataram, Mataram, Indonesia \\ ${ }^{3}$ Fakultas Ekonomi dan Bisnis, Universitas Mataram, Mataram, Indonesia
}

DOI: $\underline{10.29303 / \text { jpmpi.v3i1.392 }}$

Sitasi: Sukenti, K., Rosida, N.Y., Rosalina, D. (2020). Produk Inovasi Es Krim Kelor (Moringa oleifera Lam.) sebagai Upaya Pencegahan Stunting Desa Jatisela, Kecamatan Gunung Sari, Lombok Barat. Jurnal Pengabdian Magister Pendidikan IPA, 3(1). doi: https:// doi.org/10.29303/jpmpi.v3i1.392

*Corresponding Author: Kurniasih Sukenti, Fakultas Matematika dan Ilmu

Pengetahuan Alam,

Universitas Mataram,

Mataram, Indonesia;

Email:

kurniasihsukenti@yahoo.com

\begin{abstract}
Abstrak: Desa Jatisela, Kecamatan Gunungsari, Kabupaten Lombok Barat merupakan salah satu desa pemekaran. Di desa ini masyarakat sudah memiliki pengetahuan kesehatan yang memadai. Angka stunting di desa Jatisela menurut data Puskesmas setempat adalah zero dalam tiga tahun terakhir, namun masyarakat desa ini belum memperhatikan masalah asupan gizi. Oleh karena itu daun kelor (Moringa oleifera Lam.) sebagai sumberdaya tumbuhan yang cukup mudah dijumpai di wilayah ini dapat menjadi bahan baku produk inovasi dalam pencegahan stunting dan pemenuhan gizi ibu hamil dan anak-anak. Daun kelor yang diolah menjadi es krim mengandung zat gizi yang tinggi, terutama protein dan kalsium. Mitra kegiatan ini adalah ibu-ibu PKK Desa Jatisela. Pengolahan produk inovasi es krim kelor dilaksanakan melalui beberapa metode, yaitu: (1) pelatihan produksi; (2) pendampingan produksi hingga pemasaran. Secara umum kegiatan ini cukup baik dalam membantu permasalahan yang dihadapi mitra, yaitu memenuhi asupan gizi sehingga terhindar dari permasalahan stunting. Hal positif lain yang diperoleh adalah adanya diversifikasi pangan berbahan dasar daun kelor.
\end{abstract}

Kata Kunci: Daun kelor; es krim; stunting.

\section{Pendahuluan}

Stunting adalah kondisi gagal tumbuh pada anak balita akibat kekurangan gizi kronis sehingga anak lebih pendek untuk usianya (kekurangan gizi terjadi sejak bayi dalam kandungan dan pada masa awal kehidupan setelah lahir, tetapi baru tampak setelah anak berusia 2 tahun). Stunting disebabkan oleh kurang gizi kronis yang terjadi dalam 1000 hari kehidupan. Kualitas manusia ditentukan sejak masih berupa janin, sehingga ibu hamil harus menjaga asupan gizi agar pembentukan pertumbuhan dan perkembangan janin optimal (Trisnawati et al., 2016). Daun kelor dapat dijadikan sebaga alternatif sumber protein dan kalsium yang potensial untuk mencukupi kebutuhan gizi ibu hamil karena mengandung protein 3 kali lebih tinggi dari susu bubuk full cream atau 9 kali protein yoghurt dan kalsium, 17 kali lebih tinggi 
dibandingkan kalsium pada susu (Kholis dan Hadi, 2010). Dengan demikian, daun kelor sangat berpotensi untuk diolah menjadi eskrim yang dapat digunakan sebagai bahan untuk mencukupi gizi pada penderita stunting. Penambahan daun kelor untuk pembuatan eskrim sangat menbantu pemenuhan kalsium pada ibu hamil. Dalam pemenuhan protein sebanyak 67-100 gram dan kalsium $\pm 1200 \mathrm{mg}$ per hari, produk inovasi es krim kelor diharapkan menambah asupan protein dan kalsium ibu hamil (Yuliana, 2016).

Tingginya prevalensi stunting menjadi prioritas yang harus diselesaikan dengan sumber pangan lokal yang melimpah serta tinggi kandungan gizi yaitu daun kelor. Daun kelor memiliki kandungan betakaroten 4 kali wortel, 3 kali potassium, pisang, 25 kali zat besi bayam, 7 kali vitamin $C$ jeruk, 4 kali kalsium susu, 2 kali protein yougurt. Daun kelor digunakan sebagai pangan untuk mengatasi masalah kekurangan gizi pada anak-anak dan upaya untuk meningkatkan sistem kekebalan tubuh (Krisnadi, 2015; Mahmud, et al., 2019). Daun kelor memiliki kandungan gizi yang tinggi dan mudah didapatkan di lingkungan sekitar, namun masih sangat kurang beragam dalam pemanfaatannya. Masyarakat umumnya hanya memanfaatkan daun kelor sebagai makanan yang diolah menjadi sayur bening. Oleh karena itu, diversifikasi pengolahan pangan perlu diterapkan yang bertujuan untuk meningkatkan kandungan gizi serta nilai tambah dari komoditas pangan agar lebih berdaya guna bagi kebutuhan manusia (Ariani et al., 2013).

Es krim merupakan salah satu produk pangan yang disukai semua orang, dari kalangan anak-anak hingga dewasa. Pembuatan es krim menggunakan penambahan daun kelor dapat menambah kandungan gizinya, terutama protein dan kalsium. Dalam penanggulan stunting tidak hanya ditempuh dengan cara meningkatkan asupan kadar protein namun juga harus diimbangi dengan beberapa mikronutrient (zat gizi mikro). Tingginya kandungan protein dan mikronutrien pada daun kelor merupakan alasan utama digunakannya daun ini dalam mengatasi masalah kekurangan gizi pada balita, ibu hamil, dan ibu menyusui (Srikanth et al., 2014).

Terkait dengan kebutuhan Desa Jatisela dalam hal pencegahan stunting, maka perlu dilakukan pengenalan cara pembuatan produk es krim berbahan dasar daun kelor. Tujuan kegiatan ini adalah agar (1) masyarakat/mitra dapat memanfaatkan tumbuhan kelor di sekitarnya untuk diolah menjadi es krim kelor, (2) mitra mendapat transfer pengetahuan yang berdampak positif, dan (3) mitra dapat menjual es krim daun kelor untuk menambah penghasilan keluarga.

\section{Metode}

Solusi dalam pemanfaatan daun kelor dalam membantu mengatasi masalah stunting dapat dilaksanakan melalui metode: 1) Pelatihan cara pembuatan produk es krim kelor. Dalam metode ini dilakukan pembekalan atau alih teknologi, yaitu penyadaran dengan memberikan informasi dan keterampilan pada mitra tentang manfaat daun kelor, tepung daun kelor, dan produk daun kelor (es krim kelor), bagi pemenuhan gizi dan kesehatan, serta nilai ekonomi yang dapat diperoleh melalui pembuatan produk es krim kelor; 2) Pendampingan pembuatan es krim daun kelor sampai dengan dihasilkan produk es krim daun kelor; 3) Pendistribusian es krim daun kelor kepada masyarakat terutama ibu-ibu dan anak-anak.

Alat dan bahan yang digunakan dalam pembuatan es krim: alat barupa timbangan, gelas ukur, blender, panci, kompor, sendok, sutil, gelas cup es krim; bahan-bahan berupa 50 gr daun kelor, Air 100 ml, 4 sendok makan tepung maizena, 1 butir telur (ambil kuning telurnya), $1000 \mathrm{ml}$ susu full cream, 200 gr gula pasir, vanili.

Proses Pembuatan Es Krim Kelor: blender daun kelor dan $100 \mathrm{ml}$ air, kocok kuning telur hingga berbusa, panaskan susu 
cair dan gula dalam panci 3-5 menit, masukkan daun kelor yang sudah di blender dan kuning telur, aduk hingga rata, tambahkan maizena yang sudah diencerkan untuk mengentalkan adonan es krim, aduk rata, masak hingga mendidih, masukkan vanili ke dalam adonan yang sedang di aduk, tunggu hingga mendidih, tuangkan es krim dalam gelas cup es krim, masukkan es krim ke dalam es krim sekitar 7 sampai 8 jam, es krim siap dihidangkan.

\section{Hasil dan Pembahasan}

Pelatihan produksi es krim kelor dengan mengolah daun kelor menjadi produk es krim merupakan salah satu alternatif dalam usaha diversifikasi pengolahan. Produk eskrim kelor ini hadir sebagai salah satu solusi pilihan pangan bagi masyarakat luas, khususnya penderita stunting yang merupakan masalah kesehatan masyarakat yang perlu diperhatikan lebih lanjut. Penyebab langsung dari stunting adalah defisiensi energi maupun protein yang berarti kurangnya konsumsi makanan yang mengandung energi dan protein. Pertumbuhan pada awal kehidupan membutuhkan protein dengan proporsi yang tepat. Daun kelor merupakan salah satu bahan makanan nabati, sumber protein. Masalah gizi masyarakat terkait dengan ketersediaan dan aksesibilitas pangan penduduk (Badan Ketahanan Pangan, 2012).

Pelatihan produksi tentang cara membuat es krim kelor dilakukan melalui pembekalan atau alih teknologi, sehingga masyarakat menjadi sadar akan manfaat dan nilai gizi es krim kelor, serta nilai ekonomi yang berpotensi diperoleh melalui pembuatan es krim kelor. Untuk melihat peningkatan keterampilan dan pengetahuan peserta, dapat dilihat dengan melakukan tes awal dan tes akhir, dengan demikian dapat diamati indikator keberhasilan kegiatan ini. Selanjutnya diberikan penyuluhan tentang permasalahan gizi stunting dan makanan sumber protein tinggi dimana salah satunya adalah es krim kelor. Penyampaian materi ini ditujukan untuk memberikan pengetahuan bahwa produk es krim kelor bermanfaat bagi kesehatan.

Stunting disebabkan asupan energi dan protein yang kurang dari angka kecukupan gizi yang dianjurkan. Protein juga memegang peranan penting dalam proses pembentukan feritin, hemosiderin, dan hemoglobin. Sebagian masyarakat masih kurang pengetahuannya tentang menjaga asupan gizi yang baik (Kurniasih et al, 2010). Protein adalah salah satu zat gizi yang memegang peranan penting untuk pertumbuhan dan pemeliharaan jaringan tubuh. Keseimbangan protein dalam komposisi menu makan dapat menjadi penyeimbang konsumsi zat gizi makro yang lain karbohidrat dan lemak yang cenderung dapat meningkatkan resiko obesitas dan penyakit degeneratif (Almatsier, 2010). Lebih lanjut, Almatsier et al., (2011) menjelaskan bahwa fungsi utama protein adalah membentuk jaringan baru dan memperbaiki jaringan yang rusak. Jadi, protein diperlukan untuk pertumbuhan dan perkembangan dalam masa pertumbuhan serta memelihara jaringan tubuh selama usia dewasa. Fungsi protein untuk pertumbuhan dan pemeliharaan, membantu pembentukan ikatan esensial tubuh, mengatur keseimbangan air, memelihara netralisasi tubuh, pembentukan antibodi dan sebagai sumber energi (Adriani \& Wirjatmadi, 2012). Dengan adanya asupan protein yang mencukupi maka akan dapat membantu kelancaran berbagai proses metabolisme tubuh, sehingga mendukung regenerasi, pertumbuhan, dan perkembangan sel di dalam tubuh yang kemudian akan berpengaruh kepada tumbuh kembang organ-organ tubuh secara keseluruhan. Dengan proses pertumbuhan yang baik inilah maka stunting dapat diminimalisir atau bahkan dihindari. 


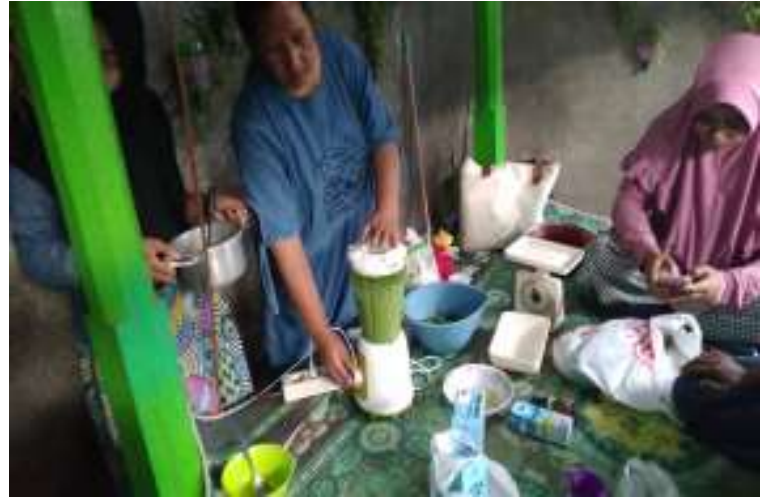

Gambar 1. Alat dan bahan yang digunakan

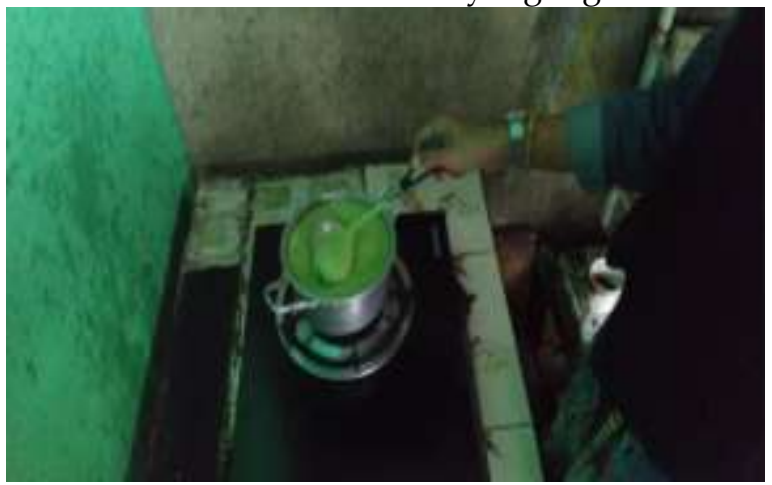

Gambar 2. Peroses pemasakan es krim kelor

Pada saat pelatihan pembuatan es krim kelor (Gambar 1), sebelumnya disampaikan pula tentang alat dan bahan yang diperlukan, serta prosedur atau tahapan dalam pembuatan es krim kelor (Gambar 2). Hal lain yang juga penting adalah penyampaian materi tentang cara pengemasan es krim kelor, dimana hal ini memiliki tujuan memberikan pengertian dan contoh langsung kemasan yang baik untuk digunakan dalam memasarkan produk (Gambar 3).

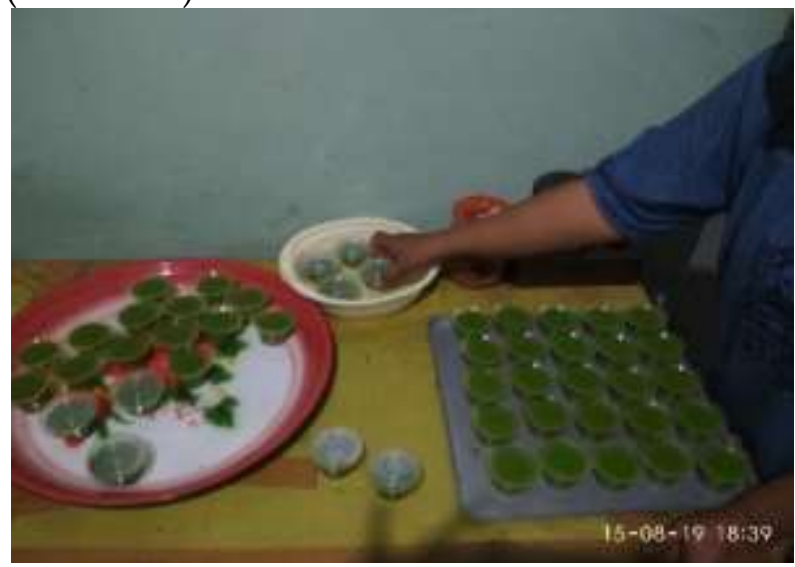

Gambar 3. Proses pendinginan dan pengemasan
Es krim kelor yang dibuat dengan tujuan selanjutnya untuk dijual atau dipasarkan harus dikemas dengan baik dan cukup aman untuk dibawa ke tempat penjualan. Kemasan pangan adalah bahan yang digunakan untuk mewadahi dan atau membungkus pangan, baik yang bersentuhan langsung dengan pangan maupun tidak. Fungsi utama pengemasan adalah untuk melindungi es krim kelor terhadap kerusakan fisik, perubahan kimia, dan kontaminasi mikroba, serta menampilkan produk agar menarik bagi konsumen.

\section{Pendistribusian Es Krim Kepada Ibu-Ibu dan Anak-anak yang ada di Desa Jatisela}

Setelah melalui proses pembuatan es krim daun kelor sampai dengan proses pembekuan es krim kelor dilakukan penditribusian dengan sasaran ibu-ibu hamil dan anak-anak yang kecil terutama di kelompok RA NW Dusun Johar Pelita. Pembagian tersebut bertujuan untuk memperkenalkan es krim daun kelor kepada masyarakat dengan respon yang baik dari masyarakat terhadap es krim daun kelor. Dengan adanya pengenalan atau sosialisasi ini, maka masyarakat akan menyadari bahwa daun kelor dapat ditingkatkan nilai gunanya dari sekedar sebagai sayuran saja menjadi bahan baku produk yang inovatif, bergizi, dan berpeluang untuk dipasarkan dan menambah pendapatan ekonomi keluarga.

\section{Pendampingan Produksi Es Krim Kelor}

Kegiatan pendampingan pembuatan es krim kelor merupakan kegiatan lanjutan dari kegiatan pelatihan pembuatan es krim kelor. Kegiatan pendampingan dimaksudkan untuk mengoptimalkan pencapaian luaran kegiatan. Kegiatan pendampingan ini juga bertujuan untuk memastikan bahwa alih teknologi dan transfer pengetahuan berjalan dengan baik, hingga ke tahap pengemasan untuk dipasarkan kepada konsumen. Dalam kegiatan ini masyarakat dapat mengkonfirmasi hal-hal terkait proses pembuatan dan berpartisipasi 
dengan intens sehingga masyarakat memperoleh manfaat yang optimal dari kegiatan ini.

\section{Kesimpulan}

Kegiatan ini dapat membantu permasalahan stunting yang dihadapi masyarakat. Target dan luaran yang diharapkan dari kegiatan ini telah tercapai, yaitu (1) masyarakat/mitra dapat memanfaatkan tumbuhan kelor di sekitarnya untuk diolah menjadi es krim kelor, (2) mitra mendapat transfer pengetahuan yang berdampak positif, dan (3) mitra dapat menjual es krim daun kelor untuk menambah penghasilan keluarga.

\section{Ucapan Terimakasih}

Penulis mengucapkan terima kasih kepada seluruh pihak yang telah berpartisipasi dan berkontribusi dalam pelaksanaan kegiatan ini, terutama jajaran Kepala Desa dan ibu-ibu PKK di Desa Jatisela, Lombok Barat.

\section{Daftar Pustaka}

Adriani \& Wirjatmadi. (2012). Peranan Gizi dalam Siklus Kehidupan. Kencana, Jakarta.

Almatsier, S. (2010). Prinsip Dasar Ilmu Gizi. Jakarta: Gramedia Pustaka Utama

Almatsier, S., Soetardjo, S. dan Soekatri, M. (2011). Gizi Seimbang dalam Daur Kehidupan. Jakarta: Gramedia Pustaka Utama.

Ariani, M., Hermanto, Hardono, G.S., Sugiarto, Wahyudi, T. S. (2013). Kajian Strategi Pengembangan Diversifikasi Pangan Lokal. Bogor: Badan Penelitian dan Pengembangan Pertanian. [serial online].

http://pse.litbang.pertanian.go.id

(Diakses tanggal 27 Agustus 2019).
Badan Ketahanan Pangan. (2012). Roadmap Diversifikasi Pangan tahun 2011-2015. Jakarta: Kementerian Pertanian.

Dirjen Bina Gizi \& KIA. (2011). Keputusan Menteri kesehatan. Jakarta: Kementerian Kesehatan RI.

Kholis, N. dan Hadi, F. (2010). Penguji Bioassay Biskuit Balita yang Disuplementasi Konsentrat Protein Daun Kelor (Moringa oleifera) Pada Model Tikus Malnutrisi. Jurnal Teknologi Pertanian Vol. 11 No.3 hal 144151.

Krisnadi, A. D. (2015). Kelor Super Nutrisi. Kunduran Blora: Moringa Indonesia.

Kurniasih dan Dedeh. (2010). Sehat dan Bugar Berkat Gizi Seimbang. Jakarta: PT Gramedia Pustaka Utama.

Mahmud, M.K., Hermana, Nazarina, Marudut, S., Zulfianto, N.A. (2018). Tabel Komposisi Pangan Indonesia (TKPI) 2017. Jakarta: Direktorat Jenderal Kesehatan Masyarakat. Direktorat Gizi Masyarakat. Kementerian Kesehatan Republik Indonesia.

Srikanth, S, V., Mangala, S., dan Subrahmanyam, G. (2014). Improvement of Protein Energy Malnutrition by Nutritional Intervention with Moringa Oleifera among Anganwadi Children in Rural Area in Bangalore India. International Journal of Scientific Study 2 (1); 1-4.

Trisnawati, Y., Purwanti, S. dan Retnowati, M. (2016). Studi Deskriptif Pengetahuan dan Sikap Ibu Hamil tentang Gizi 1000 Hari Pertama Kehidupan di Puskesmas Sokaraja Kabupaten Banyumas. Jurnal Kebidanan, VIII, (2), 175-182.

Yuliana. (2016). Uji Organoleptik dan Kadar Kalsium Es Krim dengan Penambahan Kulit Pisang dan Daun Kelor. Surakarta: Fakultas Keguruan dan Ilmu Pendidikan Universitas Muhammadiyah. 